\title{
Zamki, pałace i dwory w Polsce - rozmieszczenie i obecne wykorzystanie
}

Zarys treści: Celem rozdziału jest identyfikacja zamków, pałaców i dworów w Polsce oraz ich charakterystyka pod względem rozmieszczenia, stanu zachowania, stosunków własnościowych oraz aktualnie pełnionej funkcji. Celem pośrednim jest przedstawienie procesu zbierania danych z użyciem GIS, ocena zgromadzonych danych i wykorzystanego oprogramowania. Badania zostały przeprowadzone w ramach projektu studenckiego. Na podstawie rejestru zabytków nieruchomych Narodowego Instytutu Dziedzictwa, zgromadzono za pomocą aplikacji ArcGIS Online lokalizacje i informacje opisowe dla 4842 zamków, pałaców i dworów w Polsce. Spośród wszystkich sklasyfikowanych obiektów, blisko $53 \%$ stanowią dwory, $41 \%$ pałace i $6 \%$ zamki. Najwięcej dworów znajduje się w centrum Polski. Pałace dominują w zachodniej części kraju. Zamki zlokalizowane są głównie w południowo-zachodniej części Polski oraz w mniejszym stopniu na północy. Wśród analizowanych zabytków, $60 \%$ zostało uznanych za obiekty funkcjonujące. Blisko połowę wszystkich uwzględnionych w projekcie zamków, pałaców i dworów stanowią obiekty prywatne. Najczęściej występującą aktualnie funkcją badanych zabytków jest funkcja mieszkaniowa (18\%).

Słowa kluczowe: dziedzictwo kulturowe, zamki, pałace, dwory, GIS, ArcGIS Online.

\section{Wprowadzenie}

Systemy Informacji Geograficznej (GIS) mogą być zastosowane wszędzie tam, gdzie istnieje odniesienie przestrzenne, gdzie można określić położenie obiektu w przestrzeni geograficznej, co powoduje, że systemy te są wykorzystywane w wielu dziedzinach i badaniach naukowych, w tym w badaniach dziedzictwa kulturowego (Jażdżewska 2010). System informacji geograficznej jest komputerowym systemem informacyjnym, który umożliwia pozyskiwanie, modelowanie, przechowywanie, odzyskiwanie, udostępnianie, analizę i prezentację danych geograficznych (Worboys, Duckham 2004). Ze względu na innowacyjne możliwości łączenia geograficznej i kartograficznej reprezentacji cech zawartych w bazach danych, GIS jest coraz częściej wykorzystywany w badaniach dotyczących zachowania dziedzictwa kulturowego zarówno na szczeblu lokalnym, jak i krajowym. Zastosowanie technologii GIS pozwala na wizualizację rozmieszczenia 
zabytków, a także przeprowadzenie różnego rodzaju analiz (Spiridon, Ursu, Sandu 2016). Wiele prac przedstawia wykorzystanie systemów informacji geograficznej w badaniach dziedzictwa kulturowego. Spośród nich można wyodrębnić takie, które wykorzystują możliwości GIS do przechowywania, analizowania i wizualizacji danych dotyczących różnego rodzaju składników dziedzictwa kulturowego (Szajnowska-Wysocka, Tkocz 2008; Rząsa, Ciski, Ogryzek 2019), przedstawiają proces tworzenia bazy danych i związanych z nim problemów oraz zarządzanie dziedzictwem kulturowym za pomocą technologii GIS (Hosse, Schilcher 2003; Chias i in. 2006; Seker i in. 2010; He i in. 2015; Spiridon, Ursu, Sandu 2016; Szady 2016), przedstawiają różnego rodzaju technologie komercyjne i typu open source (Rinaudo, Agosto, Ardissone 2007; Meyer i in. 2007), czy skupiają się na zastosowaniu w dokumentacji architektury zabytków nowych technologii, takich jak modelowanie 3D, teledetekcja i fotogrametria (Droj 2010; Toz, Duran 2004; Seker i in. 2010; Yakar, Doğan 2018).

Dziedzictwo kulturowe jest pojęciem trudnym do zdefiniowania, złożonym z wielu aspektów. Jest to, w najprostszej definicji, świadectwo życia byłych pokoleń. Dziedzictwo kulturowe można podzielić na dorobek kultury materialnej i dorobek kultury duchowej. Składnikami kultury materialnej są wszystkie obiekty, które można zlokalizować i opisać (zabytki ruchome, nieruchome, archeologiczne), natomiast kultura duchowa składa się z wielu elementów trudnych do jednoznacznego określenia, umiejscowienia w przestrzeni, bowiem są to m.in. tradycje, umiejętności, wierzenia czy folklor (Hełpa-Liszkowska 2013). Dziedzictwo kulturowe to historia narodu, a jego ochrona oznacza ochronę historii i tożsamości narodowej. Identyfikacja obecnego stanu dziedzictwa kulturowego jest ważna dla dokumentacji i konserwacji zabytków (Yakar, Doğan 2018). Podstawę prawną ochrony dziedzictwa kulturowego w Polsce stanowi Ustawa o ochronie zabytków i opiece nad zabytkami z dnia 23 lipca 2003 roku . Ustawa ta głównie określa przedmiot, zakres i formy ochrony zabytków oraz opieki nad nimi. Zgodnie z zapisem ustawy, zabytkiem jest nieruchomość lub rzecz ruchoma, ich części lub zespoły, które są dziełem człowieka bądź są związane z jego działalnością i stanowią świadectwo zdarzenia lub całej epoki, których ochrona jest ważna ze względu na ich wartość historyczną, artystyczną czy naukową. W Polsce wyróżnia się kilka form ochrony zabytków:

- wpis na Listę światowego dziedzictwa UNESCO,

- wpis do rejestru zabytków,

- wpis na Listę Skarbów Dziedzictwa,

- uznanie za pomnik historii,

- utworzenie parku kulturowego,

- ustalenia ochrony $\mathrm{w}$ miejscowym planie zagospodarowania przestrzennego albo w szczególnych decyzjach w związku z określonymi inwestycjami.

\footnotetext{
${ }^{1}$ Dz.U., 2003, nr 162, poz. 1568.
} 
Najbardziej powszechną formą ochrony zabytków w Polsce jest wpis do rejestru zabytków. Rejestr ten prowadzi się osobno dla zabytków nieruchomych, ruchomych i archeologicznych. Narodowy Instytut Dziedzictwa gromadzi decyzje o wpisie do rejestru zabytków z terenu całego kraju, których dostarczenie jest obowiązkiem Wojewódzkich Konserwatorów Zabytków. Rejestr ulega ciągłym zmianom. Dodawane są nowe zabytki, część jest skreślana ze względu na zniszczenie czy utratę wartości zabytkowych, a część jest uzupełniana i zmieniana. Jest on kwartalnie aktualizowany, jednak należy pamiętać, że nie zawiera wszystkich aktualnych danych ${ }^{2}$.

Zgodnie z wcześniej wymienioną ustawą, w rejestrze zabytków nieruchomych umieszczane są zabytki będące w szczególności:

- krajobrazami kulturowymi,

- układami urbanistycznymi, ruralistycznymi i zespołami budowlanymi,

- dziełami architektury i budownictwa,

- dziełami budownictwa obronnego,

- obiektami techniki,

- cmentarzami,

- parkami, ogrodami i innymi formami zaprojektowanej zieleni,

- miejscami upamiętniającymi wydarzenia historyczne bądź działalność wybitnych osobistości lub instytucji.

Wśród tych rodzajów zabytków szczególnie ważną grupę stanowią zamki, pałace i dwory, bardziej szczegółowo opisane w trzeciej części rozdziału. W Polsce znaleźć można wiele tego typu obiektów, które są często niedoceniane i mało poznane. Różnią się położeniem, stylem architektonicznym, własnością, stanem zachowania, a także obecnie pełnioną funkcją (Kozak 2008). Istnieje niewiele prac podejmujących zagadnienie rozmieszczenia i lokalizacji tych zabytków w skali całej Polski. Znaleźć można prace zawierające jedynie zestawienia tabelaryczne zabytków według województw (Kozak 2008; Ziółkowska-Weiss, Popiel 2014; Jasiński 2015) lub opracowania dotyczące zabytków określonego regionu (Szajnowska-Wysocka, Tkocz 2008; Siniecka, Bogacka 2018; Rząsa, Ciski, Ogryzek 2019). Wiele prac związanych jest z badaniami zamków, pałaców i dworów według pełnionej przez te obiekty funkcji, jak badania B. Krakowiak i J. Latosińskiej (2009), ukazujące placówki muzealne w dawnych rezydencjach, czy badania dotyczące usług hotelarskich w zabytkowych rezydencjach autorstwa R. Rouby (2010) oraz R. Rouby i W. Cudnego (2010). W Polsce brakuje jednej wspólnej przestrzennej bazy danych odnośnie zamków, pałaców i dworów wraz z aktualnymi opisami uwzględniającymi różne cechy obiektów. Niniejszy rozdział ma być próbą uzupełnienia luki w tym zakresie.

\footnotetext{
${ }^{2}$ https://nid.pl (dostęp: 20.08.2020).
} 
Celem rozdziału jest identyfikacja zamków, pałaców i dworów w Polsce oraz ich charakterystyka pod względem rozmieszczenia, stanu zachowania, stosunków własnościowych oraz aktualnie pełnionej funkcji, na podstawie wyników projektu studenckiego. Celem pośrednim jest przedstawienie procesu zbierania danych z użyciem GIS, ocena zgromadzonych danych i oprogramowania GIS w badaniach dziedzictwa kulturowego.

Badania składały się z dwóch etapów:

1) gromadzenia danych przestrzennych i opisowych w ArcGIS Online przez studentów na podstawie opracowanego przez autorki schematu badań i instrukcji, 2) analizy statystycznej i kartograficznej wykonanych przez autorki na podstawie zebranych danych.

Na podstawie rejestru zabytków nieruchomych wyszukiwano wpisów odnośnie zamków, pałaców i dworów oraz tworzono listę tych obiektów. Następnie każdy z 24 uczestników projektu miał za zadanie określić i wprowadzić w aplikacji lokalizację przydzielonych mu zabytków oraz odnaleźć informacje na ich temat i dodać je jako atrybuty obiektów (dokładny opis prac znajduje się w rozdziale 2). Zgromadzone dane zostały poddane dalszej analizie statystycznej. Wyniki analiz zostały zwizualizowane na wykresach i mapach (rozdział 4 i 5). Autorki pragną zaznaczyć, że zdecydowały się przedstawić wyniki projektu studenckiego wraz z oceną ich przydatności, dokładności i rzetelności oraz podkreślić, że mają świadomość, że są to wstępne wyniki badań. Są jednak przekonane, że powstała baza danych jest cennym źródłem informacji i może stanowić punkt wyjścia do dalszych analiz.

\section{Metody i źródła danych}

Dane o zamkach, pałacach i dworach w Polsce zostały zebrane przez 24 studentów III roku kierunku: geoinformacja, w trakcie zajęć z przedmiotu: „System GIS w informacji turystycznej - projekt grupowy", na Wydziale Nauk Geograficznych Uniwersytetu Łódzkiego w semestrze zimowym 2019/2020. Na podstawie rejestru zabytków nieruchomych Narodowego Instytutu Dziedzictwa, z aktualnością na dzień 30 września 2019 roku, studenci przeszukiwali wykazy poszczególnych województw i wybierali tylko zamki, pałace i dwory. Ustalono, że obiekty, które posiadały w rejestrze adnotacje, że już nie istnieją, nie będą umieszczane na liście. Następnie zebrane dane zostały podzielone na 24 zestawy. Obiekty były porządkowane względem położenia w określonym województwie i powiecie oraz zliczane. Niektóre zestawy zawierały listę zabytków z jednego województwa, inne obejmowały obiekty z różnych obszarów tak, aby były podobne pod względem liczby zabytków. Każdy ze studentów losował zestaw, z którym pracował przez całe zajęcia. 
Zadaniem studentów było wprowadzenie obiektów znajdujących się na liście za pomocą systemów informacji geograficznej, w tym przypadku ArcGIS Online. Jest to usługa działająca w chmurze, umożliwiająca połączenie informacji o osobach, miejscach, lokalizacjach i różnych danych za pomocą interaktywnych map. ArcGIS Online pozwala na współpracę z innymi użytkownikami przy budowaniu map i aplikacji, zbieranie, aktualizowanie i przetwarzanie danych w systemie oraz zarządzanie dostępem do zgromadzonych danych ${ }^{3}$. Wykorzystanie systemów informacji geograficznej zdecydowanie usprawniło pracę zespołu. Systemy informacji geograficznej złożone są bowiem z kilku ważnych elementów: ludzi - specjalistów określonej dziedziny, danych z atrybutami przestrzennymi, komputera i odpowiedniego oprogramowania. GIS umożliwia gromadzenie różnych informacji przestrzennych, ich edytowanie, przetwarzanie, a następnie udostępnianie i analizowanie (Jażdżewska 2010). Wykorzystując funkcjonalność ArcGIS Online, na potrzeby projektu utworzono grupę, do której dołączyło 24 studentów kierunku: geoinformacja oraz osoby prowadzące zajęcia. Przed przystąpieniem do pracy niezbędne było przygotowanie projektu: dodanie podkładu mapy i niezbędnych warstw oraz wprowadzenie ustawień i funkcji ułatwiających pracę. Dane zbierane były w 3 warstwach, osobno dla zamków, pałaców i dworów. Wykonanie zadania wymagało także skonfigurowania parametrów tych warstw:

- włączono możliwość edycji warstw, zarówno atrybutów, jak i geometrii,

- włączono synchronizację danych oraz śledzenie, kto z użytkowników utworzył dany obiekt oraz kto, jako ostatni go aktualizował,

- włączono widoczność wszystkich obiektów dla wszystkich użytkowników.

Oprócz zlokalizowania danego obiektu i umieszczenia go na mapie w postaci punktu, należało wypełnić szereg atrybutów:

- nazwa własna,

- miejscowość/województwo/powiat/gmina,

- makroregion według Kondrackiego,

- położenie historyczne,

- położenie komunikacyjne,

- właściciel/fundator,

- czas powstania,

- typ zamku/założenie pałacowe/założenie dworskie,

- położenie względem ukształtowania terenu,

- projektant/architekt,

- układ przestrzenny,

- styl architektoniczny,

- dyspozycja kondygnacji,

- otoczenie,

\footnotetext{
${ }^{3}$ https://www.esri.com (dostęp: 17.08.2020).
} 
- przebudowy,

- stan zachowania,

- własność,

- obecna funkcja,

- ważne wydarzenia,

- ciekawostki.

W niniejszym opracowaniu przeanalizowane zostały jedynie trzy cechy: stan zachowania, własność oraz obecna funkcja. W celu ułatwienia pracy studentów, przed rozpoczęciem ćwiczeń skonfigurowano okna podręczne poszczególnych warstw, gdzie wyłączono z edycji atrybuty nieistotne z punktu widzenia projektu, takie jak id czy data edycji oraz ustalono podpowiedzi, które miały ułatwić pracę i wyjaśnić co oznaczają i jakich informacji wymagają poszczególne atrybuty (ryc. 1).

\section{Konfiguruj atrybuty}

Zaznacz, które pola mają być wyáwietlone i edytowane. Wybierz pole, aby zmienić jego alias, okreálić jego pozycjẹ i sformatować je.

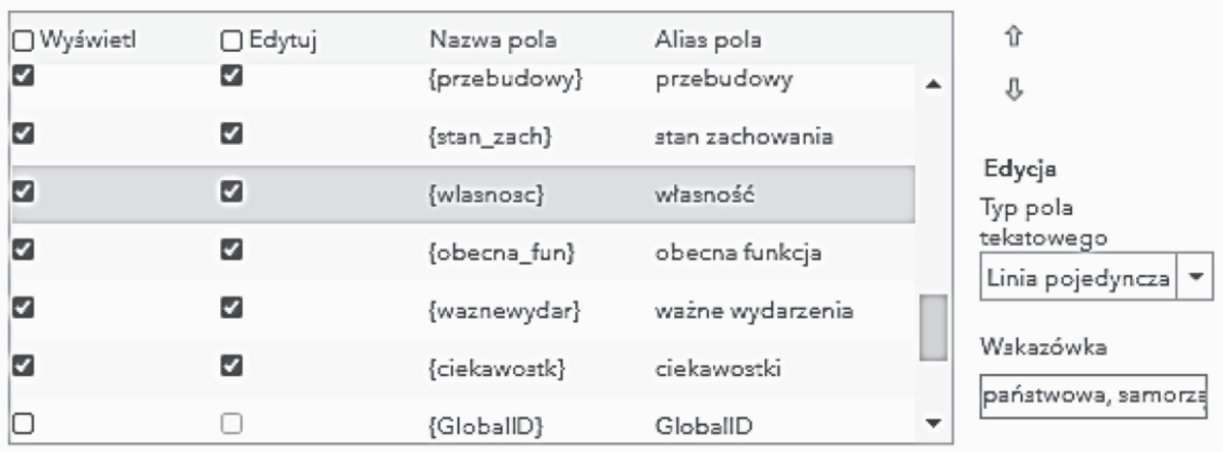

Ryc. 1. Konfiguracja atrybutów edytowanych warstw w ArcGIS Online Źródło: oprac. własne

Warstwami pomocniczymi w określaniu lokalizacji zabytków były mapa bazowa dostępna w portalu ArcGIS Online - zobrazowania z etykietami, a także mapa topograficzna i drogowa, wybrane z ArcGIS Living Atlas oraz zabytki nieruchome dołączone za pomocą usługi WMS Inspire. Atrybuty zabytków zostały pozyskane ze źródeł internetowych, książek, rejestru zabytków nieruchomych, prasy oraz w nielicznych przypadkach z inwentaryzacji w terenie, rozmów z mieszkańcami okolicznych terenów, właścicielami zabytków i pracownikami różnych instytucji. Łącznie wstawiono 4842 punkty reprezentujące zabytki, w tym 307 zamków, 2557 dworów i 1978 pałaców (ryc. 2). 


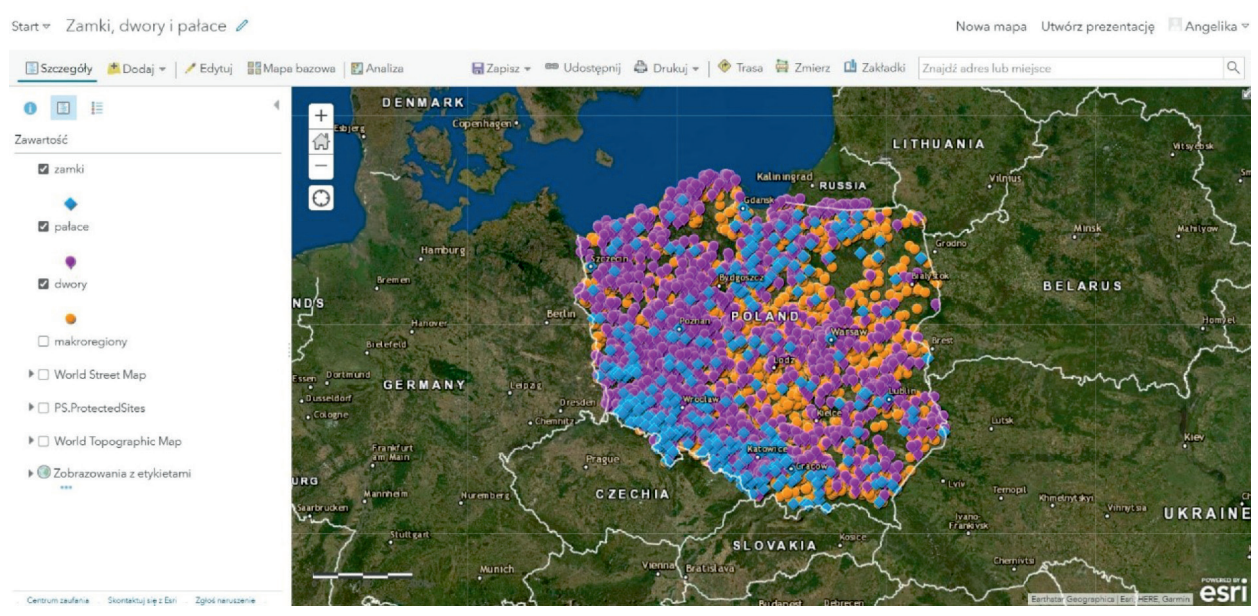

Ryc. 2. Widok mapy w portalu ArcGIS Online

Źródło: oprac. własne

\section{Zamki, pałace i dwory jako przykłady dziedzictwa kulturowego}

Zamki, pałace i dwory ${ }^{4}$ można określić mianem zabytkowych rezydencji ${ }^{5}$, które stanowią znaczącą część dziedzictwa kulturowego kraju. To dzieła architektury i budownictwa współtworzące krajobraz kulturowy Polski. Rezydencje te powstawały od czasu kształtowania się państwowości polskiej do drugiej wojny światowej. Były to najpierw zamki i dwory obronne (średniowieczne i renesansowe), a następnie pałace i dwory barokowe, klasycystyczne oraz te wznoszone w dobie historyzmu i eklektyzmu.

Zamek to „zespół elementów warownych i budynków mieszkalnych powiązanych w zamknięty obwód obronny, zespół, który powstał w ustroju feudalnym jako ośrodek władzy książęcej, siedziba możnowładcy, siedziba rycerza lub placówka militarna. Zasadniczą cechę takiego zespołu stanowi zamknięty

${ }^{4} \mathrm{~W} 1659$ roku powstało opracowanie „Krótka nauka budownicza dworów, pałaców, zamków podług nieba i zwyczaju polskiego", https://jbc.bj.uj.edu.pl (dostęp: 9.02.2021). Dzieło, z którego korzystali późniejsi badacze zamków, pałaców i dworów przypisuje się Łukaszowi Opalińskiemu, a wydane zostało w Krakowie „u wdowy i dziedziców Andrzeja Piotrowczyka Jego Królewskiej Mości typologa” (Rydel 2012: 11).

${ }^{5}$ Zamki, pałace i dwory w niniejszym opracowaniu nazywane są wspólnym określeniem „zabytkowe rezydencje” lub „obiekty rezydencjonalne”. Poza funkcją obronną w przypadku zamków czy reprezentacyjną w przypadku pałaców i dworów, obiekty te pełniły funkcję mieszkalną dla swoich właścicieli/gospodarzy (królów, książąt, rycerzy, rycerzy zakonnych, rodów arystokratycznych, szlachty itp.). 
obwód obronny, początkowo w postaci wałów lub konstrukcji drewniano-ziemnej, a w następnych okresach murowany" (Guerquin 1984: 15). Zamki można podzielić na zamki średniowieczne przystosowane do obrony pionowej (wertykalnej) i nowożytne przystosowane do obrony poziomej (horyzontalnej). Zamki średniowieczne wznoszono w stylu gotyckim i powstawały one do końca XV wieku jako zamki królewskie, książęce, rycerskie, biskupie, kapitulne oraz zakonne (krzyżackie, joannickie). Od XVI wieku, ze względu na stosowanie broni palnej, budowano zamki bastejowe, a później bastionowe - w stylu renesansowym i manierystycznym lub modernizowano zamki średniowieczne. W wieku XVII nastąpił zmierzch obronności zamków, powstawały wówczas zamki bastionowe palazzo in fortezza, traktowane również jako forma przejściowa pomiędzy zamkami i pałacami. Niewątpliwie na powstanie i rozmieszczenie zamków duży wpływ miało rozbicie dzielnicowe Polski, powstanie państwa krzyżackiego nad Bałtykiem, działalność budowlana joannitów oraz Kazimierza Wielkiego, jak również zasięg terytorialny państwa polskiego za jego panowania (Krakowiak, Latosińska 2009). Obecnie liczebność zamków w Polsce szacuje się na ponad 400 obiektów, które do naszych czasów zachowały się w bardzo różnym stanie (według rejestru Narodowego Instytutu Dziedzictwa).

Pałac to reprezentacyjna budowla pozbawiona cech obronnych i wewnętrznego dziedzińca. To typ rezydencji otwartej. Może to być pojedyncza budowla albo zespół budynków (np. pałac wraz z oficynami, pawilonami, ogrodem, parkiem i zabudowaniami gospodarczymi). Integralną częścią każdego zespołu rezydencjonalnego były budynki gospodarcze (stajnie, wozownie, ujeżdżalnie), które spełniały rolę usługową i pomocniczą w codziennym życiu jakie toczyło się w każdej rezydencji (Kozakiewicz 1976). Pałace były siedzibami możnych rodów szlacheckich. Począwszy od połowy XVII wieku powstawały na ziemiach polskich, najpierw jako barokowe i rokokowe założenia pałacowo-ogrodowe entre cour et jardin, a od końca XVIII wieku jako klasycystyczne założenia pałacowo-parkowe. Pałace budowane w późniejszych czasach to budowle wznoszone w stylu romantycznym, neogotyckim, neorenesansowym czy eklektycznym. $Z$ założenia pałace były budowlami dwukondygnacyjnymi, lecz o różnej dyspozycji kondygnacji ${ }^{6}$. Pałace typu piano nobile cechuje umieszczenie funkcji reprezentacyjnej na pierwszym piętrze, natomiast pałace typu casa di villa charakteryzuje usytuowanie pomieszczeń pełniących funkcję reprezentacyjną na parterze (Miłobędzki 1982). W obecnych granicach administracyjnych Polski znajduje się ponad 2 tys. pałaców. Są to dawne pałace polskich rodów magnackich, jak również szlachty pruskiej. Wpływ na rozmieszczenie tych obiektów mają dawne granice zaborów (Jackiewicz-Garniec, Garniec 2001; Krakowiak, Latosińska 2009; Rouba 2010).

${ }^{6}$ „Dyspozycja kondygnacji” - takiego terminu używa A. Miłobędzki (1982: 14-15) w odniesieniu do pałaców, a w szczególności do funkcji pełnionej przez poszczególne kondygnacje w obiektach pałacowych. 
Pod pojęciem dworu M. Rydel (1993: 8) rozumie „parterową siedzibę wiejską właściciela ziemskiego. Przed połową XVII wieku dwory ze względów obronnych bywały piętrowe, ale zasadniczo dwór różni się od pałacu tym, że jest to budowla jednokondygnacyjna. Podstawowym wyróżnikiem jest tu fakt, że dach dochodzi do parteru. Portyki w wielkim porządku oraz piętrowe ryzality w części środkowej nie kwalifikują budowli do pałaców. Niemniej różnica między dużym dworem a małym pałacem jest bardzo płynna". Dwory w Polsce powstawały na przestrzeni prawie tysiąca lat. Od X do połowy XVII wieku rozwijały się dwory obronne jako siedziby rycerza - ziemianina. Były to średniowieczne fortalicja, a następnie renesansowe kasztele, które z racji swej funkcji obronnej były budowlami piętrowymi. Od połowy XVII wieku do przedostatniej dekady XVIII wieku wznoszono dwory alkierzowe jako wiejskie siedziby szlachcica - ziemianina, a później dwory klasycystyczne - typowo polskie, których rozwój trwał do 1863 roku. Na przełomie XIX i XX wieku obserwuje się wpływ historyzmu i eklektyzmu na rozwój dworu polskiego oraz styl dworkowy widoczny np. w dworkach myśliwskich i plebaniach. Dwory alkierzowe i późniejsze były dworami parterowymi, otoczonymi dziedzińcem i ogrodem, sadem, zabudowaniami folwarcznymi, stawami hodowlanymi. Podstawą bytu dworów były majątki ziemskie. Podobnie jak w przypadku pałaców tak i dworów, w wyniku zawirowań dziejowych, w obecnych granicach administracyjnych kraju powstawały dwory szlachty polskiej i szlachty pruskiej na obszarach dawnego zaboru pruskiego. W obecnych granicach administracyjnych Polski znajduje się ponad 2700 dworów (Jackiewicz-Garniec, Garniec 2001; Krakowiak, Latosińska 2009). W okresie międzywojennym w Polsce, w ówczesnych granicach, było około 15 tys. dworów i 5 tys. pałaców, a ziemianie stanowili niecały 1\% ludności (ok. 250000 osób). W czasie II wojny światowej zginęło ponad 20 tys. ziemian, a kilkanaście tysięcy zostało wywiezionych na Syberię. W tym czasie wiele rodzin ziemiańskich rozproszyło się po całym świecie i ani właściciele, ani ich potomkowie do Polski nie powrócili (Rydel 2012).

Czasy II wojny światowej (okupacji niemieckiej i radzieckiej) nie były dla obiektów rezydencjonalnych łaskawe. Szczególnych zniszczeń dokonały wojska radzieckie, należy również pamiętać, że znaczna część terenów dzisiejszej Polski była przed wojną ziemiami niemieckimi, a losy II wojny światowej przed 1945 rokiem nie były rozstrzygnięte (Rouba 2010). W 1944 roku wydany został dekret o reformie rolnej, ,[...] na podstawie którego pozbawiono majątków, bez odszkodowania, wszystkich właścicieli ziemskich w Polsce. Wraz z nieruchomościami konfiskacie podlegał cały inwentarz żywy, zasiewy oraz wszelkie ruchomości, jak meble, dzieła sztuki, książki i przedmioty użytku osobistego" (Rydel 2012: 206). Dwory i pałace utraciły podstawę swej egzystencji i zaczęły chylić się ku upadkowi. Pod koniec lat 40. XX wieku (w nowej powojennej rzeczywistości), zostały w dużej mierze zaadaptowane na potrzeby ówczesnego 
społeczeństwa, zlokalizowano w nich urzędy różnego szczebla, szkoły, biura Państwowych Gospodarstw Rolnych, ośrodki zdrowia, ośrodki wypoczynkowe itp. Nieliczne przysposobiono jako biblioteki, domy kultury czy placówki muzealne. Wiele z nich uległo zniszczeniu. Po roku 1989 niektóre doczekały się lepszego losu w rękach prywatnych właścicieli, obecnie często funkcjonują jako obiekty noclegowe, hotele, obiekty gastronomiczne itp. Jak już wcześniej wspomniano, do czasów obecnych zachowało się nieco ponad 2 tys. pałaców i ponad 2700 dworów (według rejestru Narodowego Instytutu Dziedzictwa). Podobnie jak w przypadku zamków, ich stan zachowania jest bardzo zróżnicowany. W rękach potomków przedwojennych właścicieli znajduje się zaledwie 80 obiektów. Jak podaje M. Rydel (2012: 207), poza dwoma pałacami, które żyją częściowo z rolnictwa (Kurozwęki i Korczew) ,nie ma ani jednego dworu czy pałacu, który - tak jak przed wojną - żyłby z ziemi i był ciągle w rękach potomków przedwojennych właścicieli". Zdaniem cytowanego autora w Polsce istnieje około 150 dworów (łącznie z muzeami), w których „kołacze się jeszcze duch dworu”.

\section{Rozmieszczenie zamków, pałaców i dworów w Polsce}

W czasie trwania projektu studenci zidentyfikowali i wstawili do bazy danych 4842 zabytki (zamki, dwory i pałace). M. Kozak (2008) wymienił 4532 zabytki tego typu eliminując w wykazie pałace miejskie. Z kolei B. Krakowiak i J. Latosińska (2009) wykazały 5190 obiektów, określając je jako obiekty rezydencjonalne. W porównaniu do badań M. Kozaka (2008), w projekcie mniej zostało ujętych jedynie zamków (307/340). Liczba pałaców (1 978/1 754) oraz dworów (2557/2438) wyznaczonych przez studentów znacznie przewyższa ich liczbę w badaniach M. Kozaka (2008). Wśród wszystkich sklasyfikowanych obiektów ponad połowę, bo blisko $53 \%$ stanowią dwory, gdzie dla porównania zamki to niewiele ponad 6\% analizowanych zabytków (ryc. 3). Wyniki te są bardzo zbliżone do badań B. Krakowiak i J. Latosińskiej (2009), które wykazały, że 53\% wszystkich analizowanych zabytków stanowią dwory, 39\% pałace i $8 \%$ zamki.

Dwory zlokalizowane są w miarę równomiernie na całym obszarze kraju, przy czym widać ich szczególne nagromadzenie w centrum Polski. Pałace dominują z kolei w zachodniej części kraju. Zamki, których jest zdecydowanie najmniej, koncentrują się głównie w południowo-zachodniej części Polski oraz w mniejszym stopniu na północy państwa (ryc. 3).

Zgodnie z podziałem na województwa, najwięcej zabytków znajduje się w województwie wielkopolskim (775), dolnośląskim oraz mazowieckim, natomiast najmniej - w województwie podlaskim (78) i świętokrzyskim, analogicznie do badań M. Kozaka (2008). Pałace i dwory mogą stanowić pewnego rodzaju miarę rozwoju poszczególnych ziem polskich. Najmniej zabytków posiada woje- 


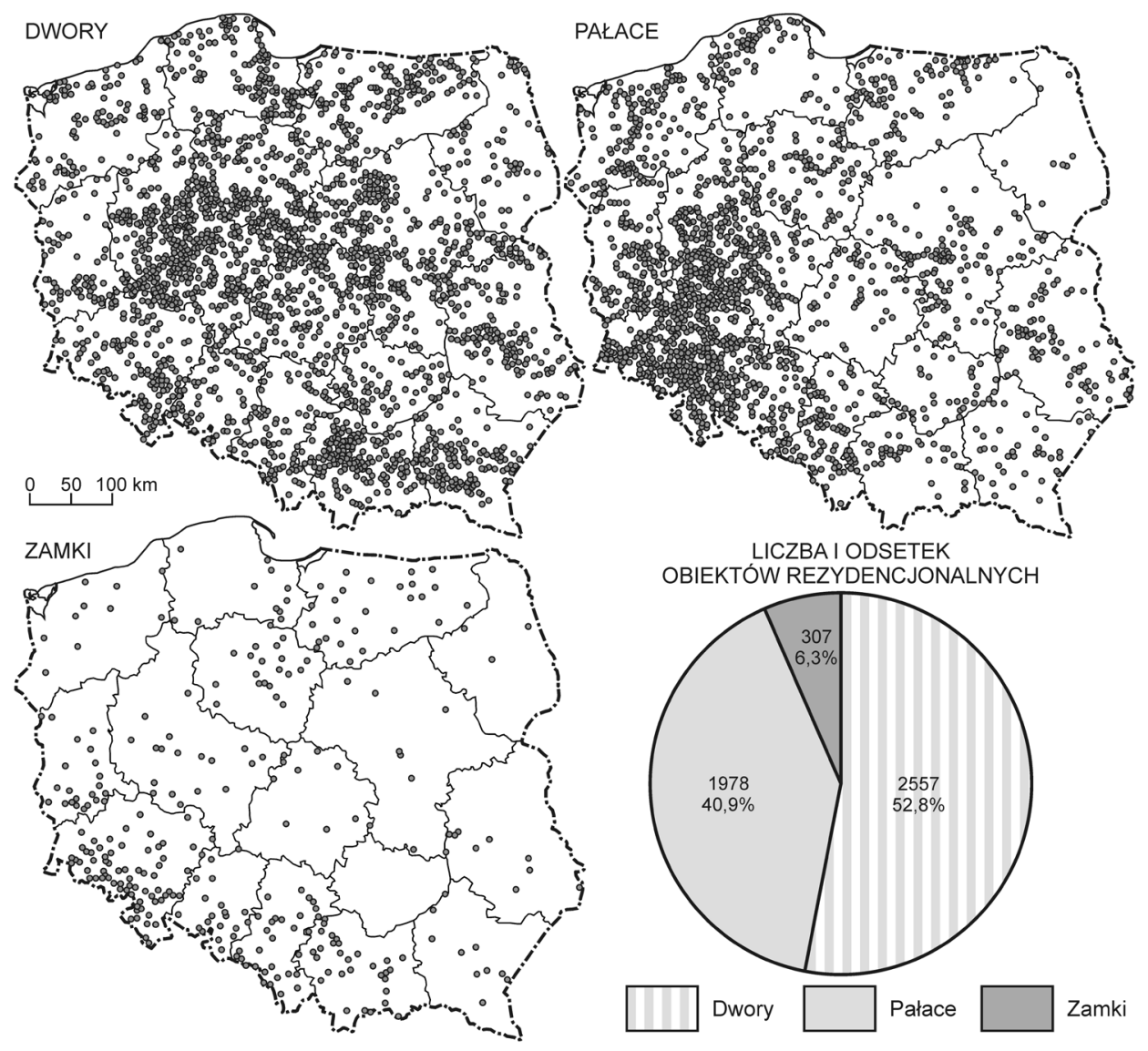

Ryc. 3. Rozmieszczenie dworów, pałaców i zamków w Polsce

Źródło: oprac. własne

wództwo podlaskie, które było pod względem gospodarczym słabiej rozwinięte i w mniejszym stopniu zaludnione niż pozostałe tereny (Kozak 2008). Zachowane zabytki przedstawiają historycznie uwarunkowaną strukturę społeczną ludności i podział na niewielką liczbę ludzi bogatych i dużą liczbę biednych (głównie małe, drewniane dwory i rzadko pojawiające się rezydencje magnackie). Wielkopolska i Śląsk, gdzie istnieje najwięcej zabytków będących świadectwem dużej zamożności społeczeństwa, są całkowitym przeciwieństwem dla Podlasia. Różne wydarzenia historyczne, w tym rozbiory czy procesy industrializacji w XIX wieku, pogłębiły różnice rozwoju gospodarczego pomiędzy wschodnią a zachodnią częścią kraju, które były widoczne już w wiekach średnich (Kozak 2008). 
W 11 województwach, w strukturze badanych zasobów dziedzictwa kulturowego dominują dwory. Najwięcej dworów znajduje się w województwie wielkopolskim (420) i mazowieckim (300). Pałace przeważają w 5 województwach położonych przy zachodniej i południowo-zachodniej granicy Polski: zachodnio-pomorskim, lubuskim, dolnośląskim, opolskim oraz śląskim (ryc. 4).

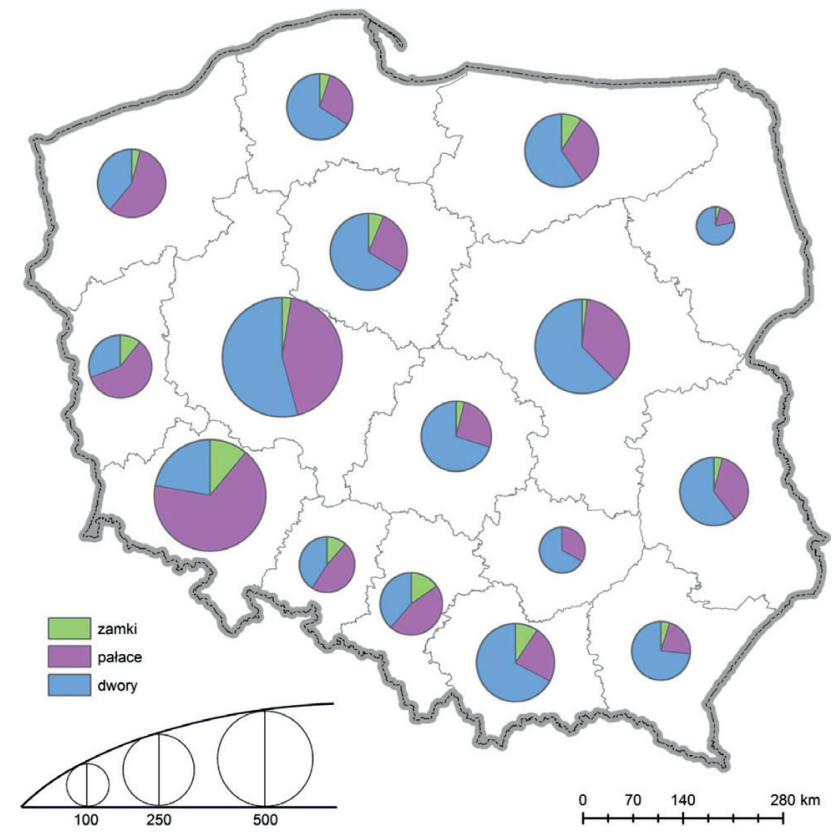

Ryc. 4. Udział zamków, pałaców i dworów w Polsce według województw (\%)

Źródło: oprac. własne

Zamki stanowią najmniej liczną kategorię spośród zabytków nieruchomych wpisanych do krajowego rejestru zabytków. Ich liczba w obecnych czasach w Polsce jest kwestią dyskusyjną. Pomimo wielu lat badań nie powstała jedna, obowiązująca i uzgodniona lista tych obiektów. Zależnie od wybranych kryteriów, definicji, a także wraz z czasem ich liczba zmienia się w poszczególnych wykazach i opracowaniach. B. Guerquin w pierwszej części publikacji Zamki w Polsce z 1974 roku wymienił 460 tego typu obiektów, a do drugiej części z 1984 roku wybrał 458. Leksykon zamków w Polsce z 2004 roku przedstawia ich 500, a Raport o stanie zabytków z 2004 roku zawiera 372 obiekty (Malawska 2007). Badania M. Kozaka z 2008 roku przedstawiają 340 tego typu zabytków. W 2015 roku, zgodnie z wykazem Narodowego Instytutu Dziedzictwa, w Polsce było 413 zamków (Koskowski 2017), a w raporcie o stanie zachowania zabytków nieruchomych w Polsce z 2017 roku jest ich 4027 .

\footnotetext{
${ }^{7}$ https://nid.pl (dostęp: 29.01.2021).
} 
Studenci $\mathrm{w}$ czasie trwania projektu zidentyfikowali i oznaczyli na mapie 307 zamków. Zamki są najbardziej widoczne w strukturze badanych zabytków w województwach położonych w południowo-zachodniej części Polski: dolnośląskie (najwięcej zamków - 74), opolskie, śląskie i lubuskie oraz małopolskie, a także na północy w województwie warmińsko-mazurskim (ryc. 4). Zamki położone na terenach dzisiejszych województw: kujawsko-pomorskiego, pomorskiego i warmińsko-mazurskiego to głównie zamki krzyżackie (teren dawnego państwa zakonnego w granicach współczesnej Polski) (Musiaka 2013). Budowaniem zamków kierowała potrzeba obronności w związku z zagrożeniami zewnętrznymi. Budowano je więc tam, gdzie były najbardziej potrzebne, co często nie miało związku z zamożnością regionu. Ten drugi aspekt był jednak kluczowy w okresie utraty walorów obronnych zamków, gdzie ich przebudowa na inne cele, np. mieszkalne wiązała się z dużymi kosztami, dlatego najwięcej z nich zachowało się na bogatszych terenach (Kozak 2008). Zamki w średniowieczu pełniły różne role, m.in. militarne, polityczne, gospodarcze, administracyjne czy kulturowe. Wraz z upływem lat i rozwojem techniki ich znaczenie malało i czasami przestawały pełnić ważne funkcje (Musiaka 2016).

\section{Stan zachowania obiektów, struktura własności i obecnie pelnione funkcje}

\section{Stan zachowania}

Oprócz lokalizacji obiektu na mapie, kluczowe było określenie kilku jego cech, m.in. stanu zachowania, własności oraz obecnie pełnionej funkcji. Studenci, na podstawie dostępnych źródeł informacji, próbowali określić podane atrybuty. W celu ułatwienia pracy, dla każdej cechy zostały zaproponowane możliwe do wpisywania wartości. Dla stanu zachowania autorki zaproponowały następujące możliwości: obiekt funkcjonujący, ruina i zabezpieczona ruina ${ }^{8}$. Spośród

${ }^{8}$ Autorki zaproponowały następujące definicje:

- „Obiekt funkcjonujący” - to obiekt użytkowany, o różnym przeznaczeniu (wykorzystany przez obiekty noclegowe placówki muzealne, oświatowe, funkcjonujący jako obiekt mieszkalny - najczęściej dwór). To obiekt mający gospodarza, który nie dopuści, by popadł on w ruinę.

- „Ruina” - to obiekt, który po opuszczeniu przez ostatnich właścicieli został pozostawiony bez jakiejkolwiek opieki, stał i nadal stoi, nie jest zagospodarowany, niszczeje, z każdym rokiem go ubywa i będzie ubywać aż zostanie całkowicie zniszczony.

- „Zabezpieczona ruina” - to obiekt opuszczony, który na pewnym etapie niszczenia został poddany pracom zabezpieczającym przed chociażby warunkami pogodowymi czy dewastacją człowieka. W wyniku prac zabezpieczających uzupełnione mogą być ubytki cegły, kamienia, mogą zostać zabezpieczone okna, obiekt może zostać ogrodzony itd. Ma zatem większe szanse na przetrwanie niż ruina. Ruina i zabezpieczona ruina mogą oczywiście interesować turystów, mogą być atrakcją turystyczną. 
wszystkich przedstawionych zabytków, $60 \%$ zostało uznanych za obiekty funkcjonujące. Stanu zachowania nie udało się określić dla około 17\% obiektów (ryc. 5). We wszystkich województwach, z wyjątkiem województwa lubuskiego, dominują obiekty uznane za funkcjonujące. W województwie lubuskim dla większości zabytków wpisano wartość „,brak danych”. Należy więc mieć na uwadze fakt, że dane, szczególnie dla tego województwa, mogą zawierać błędy i wymagają dalszych badań (ryc. 6). Studenci najmniej wykorzystywali w opisie stanu zachowania terminu - zabezpieczona ruina. Stan obiektu określony jako ruina najczęściej pojawia się w zabytkach z województwa śląskiego i świętokrzyskiego, na południu kraju oraz w województwach w północnej części Polski (ryc. 6).

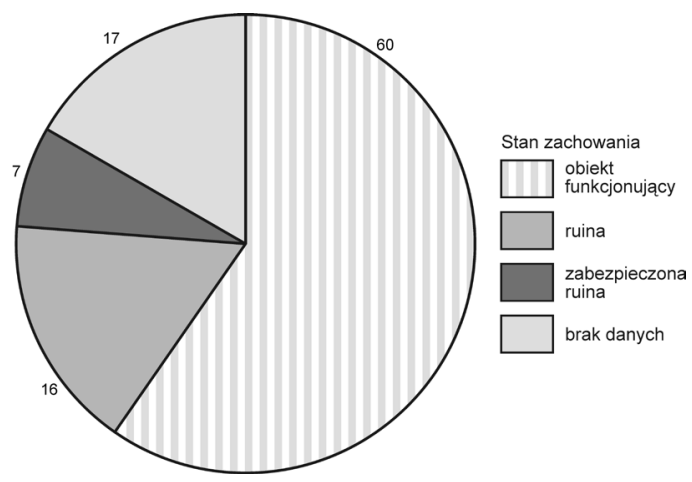

Ryc. 5. Zamki, pałace i dwory w Polsce według stanu zachowania Źródło: oprac. własne

Z uwagi na różne uwarunkowania, typy własności i pełnione funkcje, warto przedstawić także stan zachowania obiektów osobno dla zamków, pałaców i dworów. Najbardziej zbliżoną strukturę stanu zachowania do wszystkich zabytków posiadają dwory. Wynika to głównie z tego, że jest to najliczniejsza grupa badanych zabytków, która najsilniej oddziałuje na statystyki ogólne. Z przeprowadzonych badań wynika, że $60 \%$ dworów w Polsce obecnie funkcjonuje. Dla $18 \%$ obiektów z tej grupy nie udało się określić stanu zachowania (ryc. 7a). Podobnie wygląda sytuacja w przypadku pałaców $-63 \%$ to obiekty funkcjonujące (ryc. 7b). Inaczej przedstawia się stan zachowania zamków (ryc. 7c). Tutaj najwięcej, bo łącznie $43 \%$ zostało sklasyfikowanych jako ruina lub ruina zabezpieczona. Tylko 37\% z nich obecnie funkcjonuje pełniąc różne funkcje. Zamki zwykle są obiektami starszymi od większości pałaców i dworów, co przekłada się też często na ich stan zachowania. Odrestaurowanie tych obiektów wymaga odpowiedniej dbałości, dużych inwestycji i planu nowego zagospodarowania. Często ich stan jest tak zły, że można jedynie dbać o zabezpieczenie ruin, w celu zachowania choćby części elementów budowli. Niektóre zamki przeszły gruntowne remonty i pełnią obecnie różne funkcje, nie tylko turystyczne. 


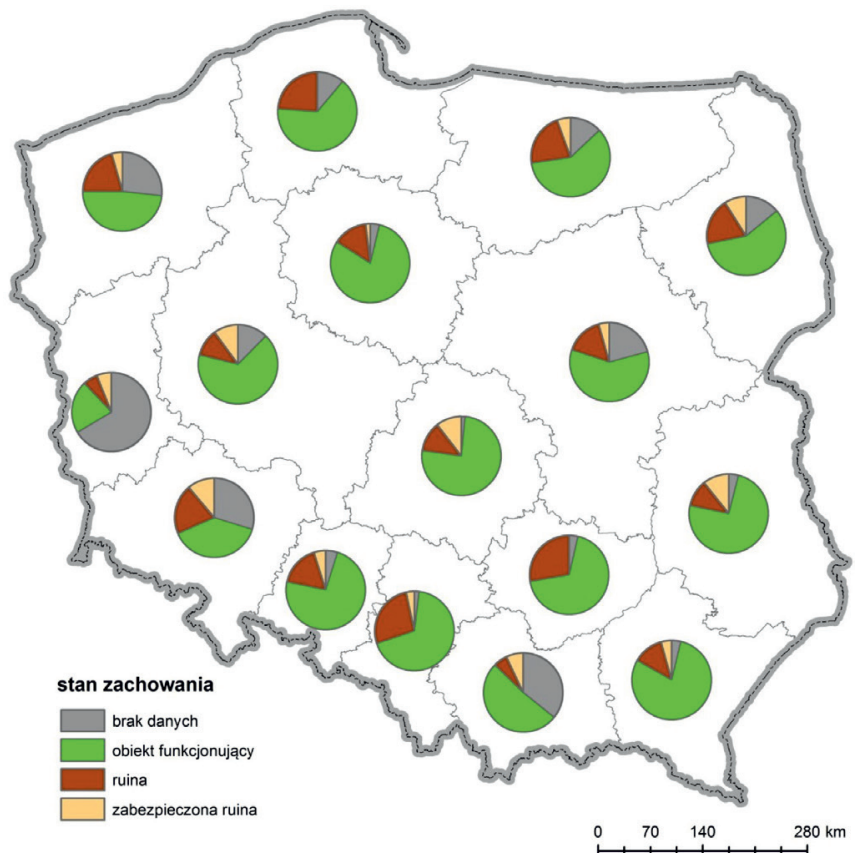

Ryc. 6. Stan zachowania obiektów rezydencjonalnych w Polsce według województw (\%)

Źródło: oprac. własne

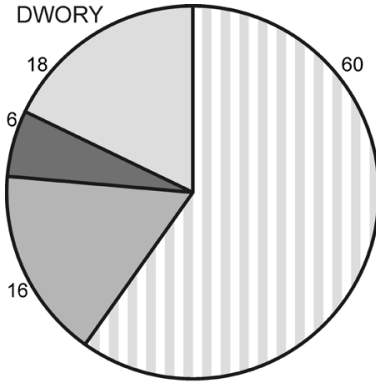

Stan zachowania

$\square$ obiekt funkcjonujący

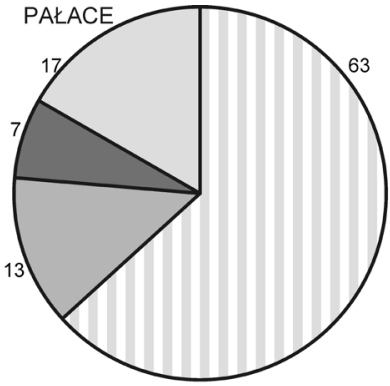

zabezpieczona ruina

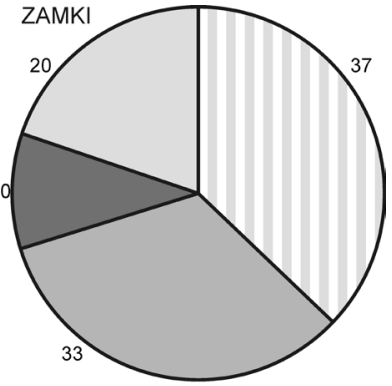

brak danych

Ryc. 7. Stan zachowania dworów, pałaców i zamków w Polsce

Źródło: oprac. własne

\section{Struktura własności}

Kolejną cechą, którą studenci mieli za zadanie określić w czasie trwania projektu była własność badanych zabytków. Tak jak w przypadku stanu zachowania, zostały wyznaczone proponowane wartości, jakie mogła przyjmować dana 
cecha. Określono, że własność może być: państwowa, prywatna, samorządowa lub kościelna. Blisko połowę wszystkich uwzględnionych w projekcie zabytków stanowią obiekty prywatne. Dla $25 \%$ zabytków nie udało się określić ich własności. Najmniej, bo zaledwie 1\% budynków jest własnością kościelną (ryc. 8).

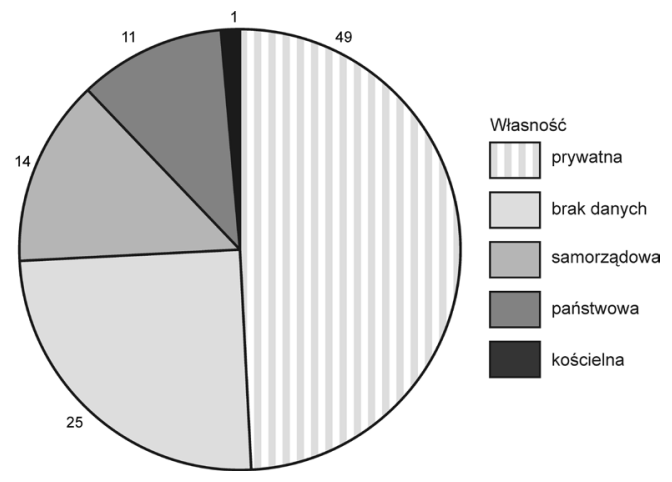

Ryc. 8. Zamki, pałace i dwory w Polsce według własności

Źródło: oprac. własne

Analizując strukturę własności zabytków w poszczególnych województwach zauważyć można, że w większości z nich dominują obiekty prywatne. Tak jak w przypadku stanu zachowania, najwięcej brakujących danych dotyczy województwa lubuskiego, a także województw: dolnośląskiego, zachodnio-pomorskiego, podlaskiego oraz małopolskiego. Najwięcej zabytków uznanych jako państwowe znajduje się w województwach: lubelskim i małopolskim, a jako samorządowe w województwach: śląskim, opolskim, świętokrzyskim oraz łódzkim (ryc. 9).

Wśród dworów zdecydowanie dominują obiekty prywatne. Niestety, aż dla $25 \%$ dworów nie udało się określić własności (ryc. 10). Odnośnie tej grupy zabytków wystąpiły największe trudności w poszukiwaniu informacji. Duża część z nich to budynki opuszczone, niszczejące, na temat których nie ma wielu powszechnie dostępnych informacji, w tym o ich własności. Ze względu na obszar badań jakim była cała Polska, krótki okres realizacji projektu oraz brak finansowania badań, ograniczono się jedynie do pozyskiwania informacji zdalnie, za pomocą literatury i źródeł internetowych. Obserwacja w terenie należała do rzadkości i dotyczyła tylko kilku dworów znajdujących się w pobliżu miejsca zamieszkania studentów. Czasami również kontaktowano się telefonicznie z instytucjami sprawującymi opiekę nad zabytkami, np. z urzędami gmin, na których terenie znajdował się określony budynek. Sytuacje te należały jednak do rzadkości, a w pozyskiwaniu informacji najczęściej wykorzystywane były strony internetowe, gdzie o mało znanych obiektach nie było umieszczonych wielu informacji. Nie znaleziono żadnego dworu należącego do majątku kościelnego. 


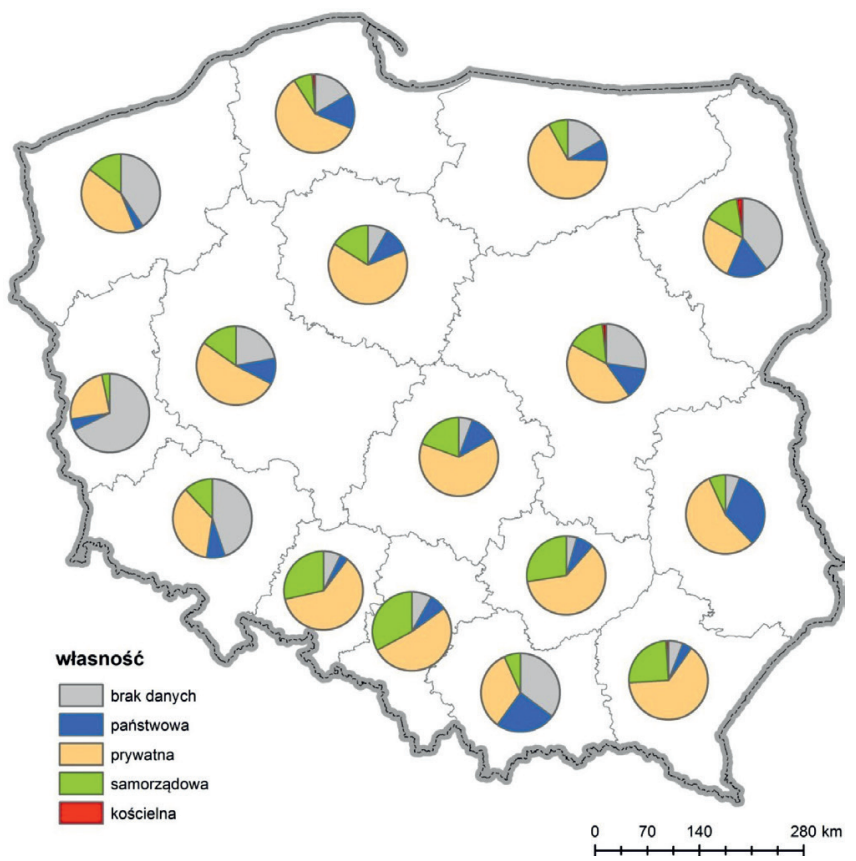

Ryc. 9. Struktura własności obiektów rezydencjonalnych w Polsce według województw (\%)

Źródło: oprac. własne
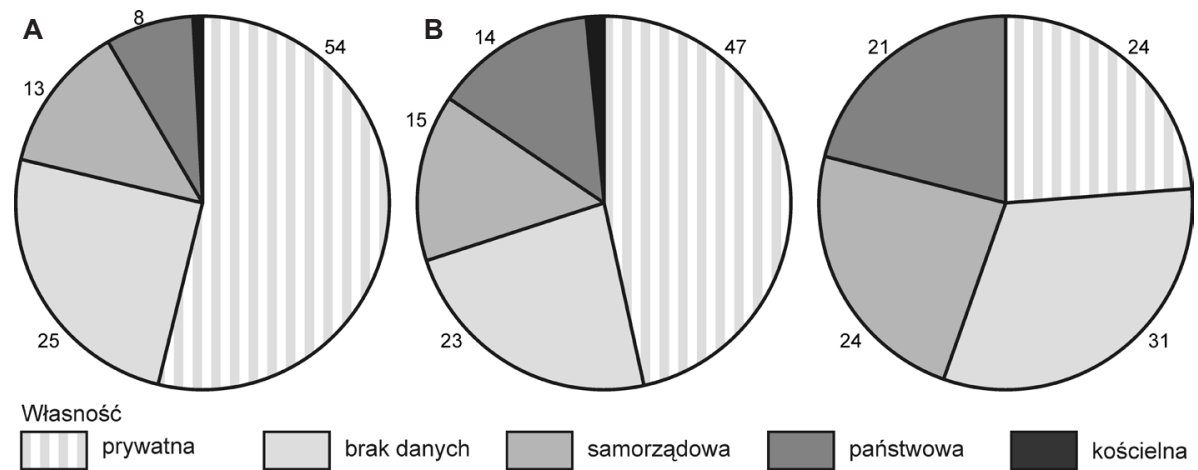

Własność

prywatna

brak danych

samorządowa

panstwowa

Ryc. 10. Struktura własności dworów (A), pałaców (B) i zamków (C) w Polsce Źródło: oprac. własne

W przypadku pałaców, struktura własności nieznacznie różni się od dworów. Większość również stanowi własność prywatną, jednak w mniejszym stopniu niż w przypadku dworów. Więcej odnaleziono natomiast pałaców, które są własnością państwa. Pozostałe typy własności różnią się względem dworów nieznacznie (ryc. 10). 
Inaczej wygląda natomiast struktura własności wśród zamków. Niestety, dla ponad 30\% zamków nie dało się ustalić czyją są własnością. Nie ma jednego dominującego typu własności. Zauważa się spadek własności prywatnej (21\%), 45\% jest własnością państwową lub samorządową (ryc. 10). Do czasu przemian ustrojowych w Polsce prawie wszystkie zamki były własnością państwa, które decydowało o prowadzonych w nich pracach i je finansowało (Malawska 2007). Transformacja ustrojowa i mechanizmy rynkowe uruchomiły procesy przechodzenia zamków z rąk państwowych w prywatne, jednak według M.R. Koskowskiego (2017) około $75 \%$ zamków w Polsce nadal pozostaje w rękach podmiotów prawa publicznego.

\section{Obecnie pełniona funkcja}

Zamki, pałace i dwory są ważną częścią dziedzictwa kulturowego Polski, nie tylko w sensie materialnym, ale również symbolicznym. Pierwotna, historyczna funkcja tych obiektów współcześnie albo całkowicie zanikła albo uległa ogromnym przeobrażeniom. Obecnie zamki nie pełnią już roli obiektów obronnych, pałace nie są siedzibami możnych rodów arystokratycznych, a dwory siedzibami zamożnych właścicieli ziemskich. Wśród tego typu zabytków dominują głównie funkcje muzealne, kulturalne, gastronomiczne, hotelowe, a także w szerokim zakresie usługi publiczne (Kozak 2008).

Tak jak w przypadku poprzednich atrybutów, przy określaniu funkcji obiektów studenci otrzymali propozycje, jak należy je klasyfikować. Na podstawie udzielanych wpisów, autorki podzieliły je na następujące kategorie:

- atrakcja turystyczna/do zwiedzania,

- hotel/restauracja,

- instytucja kulturalna,

- instytucja publiczna,

- muzeum,

- obiekt nieużytkowany/w remoncie/ruina,

- obiekt biurowy/usługowo-handlowy,

- obiekt mieszkalny/gospodarstwo rolne/agroturystyka,

- obiekt sakralny/kościelny/zakonny.

Zadanie to nie należało do najłatwiejszych, szczególnie jeżeli weźmiemy pod uwagę obiekty mało znane, których wygląd nie zawsze jasno wskazuje, że są to obiekty zabytkowe, a w internecie i innych powszechnie dostępnych źródłach danych nie ma na ten temat żadnych informacji. Dlatego dla ponad $40 \%$ wszystkich analizowanych zabytków nie udało się określić obecnie pełnionej funkcji. $\mathrm{Z}$ pewnością, gdyby badania rozszerzyć o badania terenowe, odsetek brakujących informacji byłby mniejszy. Należy mieć jednak na uwadze, że przeprowadzone badania były projektem studenckim, który nie był finansowany oraz był bardzo ograniczony w czasie. Z pozyskanych informacji wynika, że najwięcej 
spośród wszystkich analizowanych zabytków stanowią obiekty pełniące funkcję mieszkalną (wraz z gospodarstwem rolnym i gospodarstwem agroturystycznym) (18\%), następnie funkcję związaną z instytucjami publicznymi (13\%), funkcję noclegową i gastronomiczną (9\%) i w mniejszym stopniu są to obiekty nieużytkowane, ruiny lub będące w remoncie (ryc. 11).
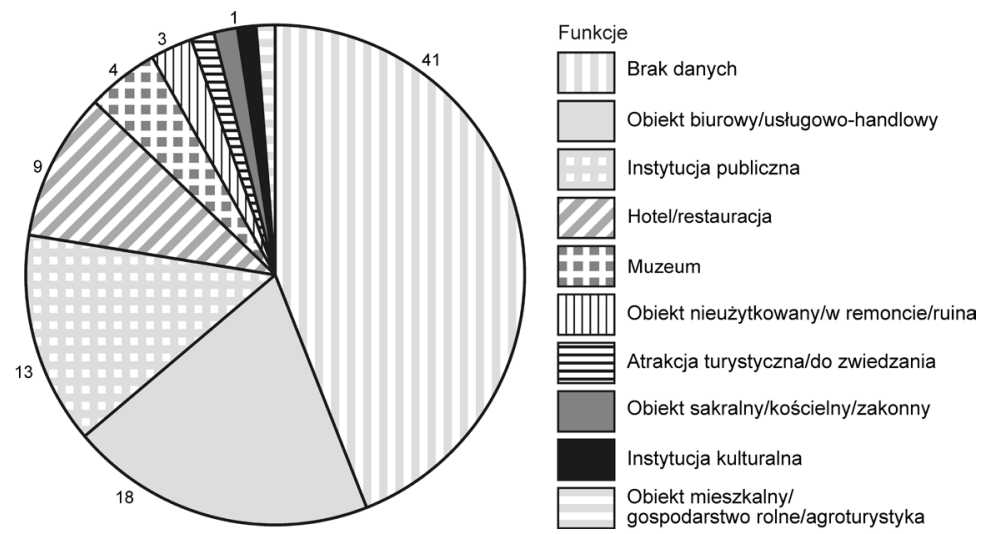

Ryc. 11. Obiekty rezydencjonalne w Polsce według obecnie pełnionej funkcji Źródło: oprac. własne

Ze względu na różny charakter analizowanych zabytków, warto przedstawić funkcje obiektów w podziale na dwory, pałace i zamki. W przypadku dworów dla $42 \%$ budynków nie określono obecnie pełnionej funkcji. Wśród pozostałych dominują obiekty mieszkalne, gospodarstwa rolne lub agroturystyczne $(25 \%)$, wyróżniają się jeszcze instytucje publiczne oraz budynki nieużytkowane, będące ruiną lub w remoncie (ryc. 12).
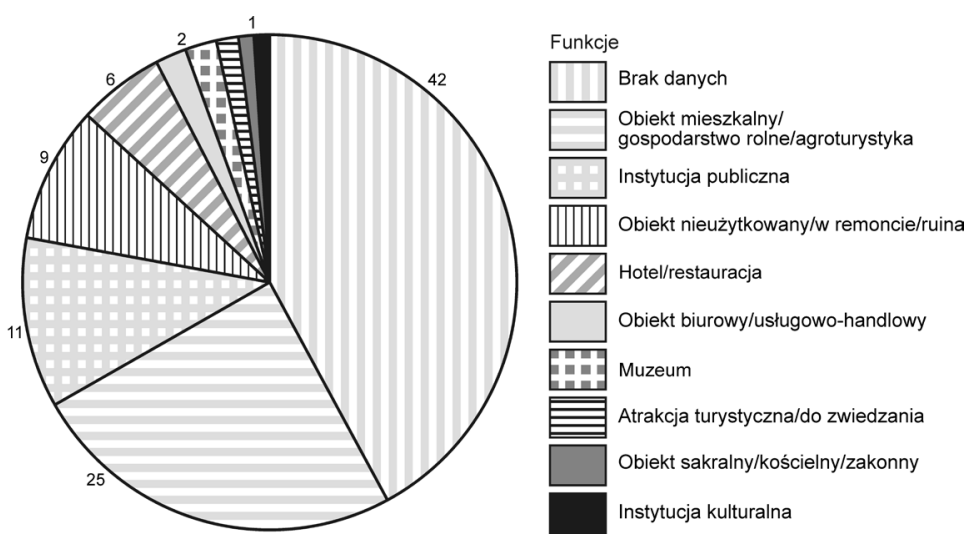

Ryc. 12. Dwory w Polsce według obecnie pełnionej funkcji

Źródło: oprac. własne 
W przypadku pałaców, struktura obecnie pełnionej funkcji nieznacznie się różni. Podobny jest odsetek obiektów, dla których brakuje danych. Wśród pozostałych dominują instytucje publiczne (18\%). Następnie na wyróżnienie zasługują budynki mieszkalne, gospodarstwa rolne lub agroturystyczne, a także obiekty, w których mieszczą się hotele lub restauracje (ryc. 13).
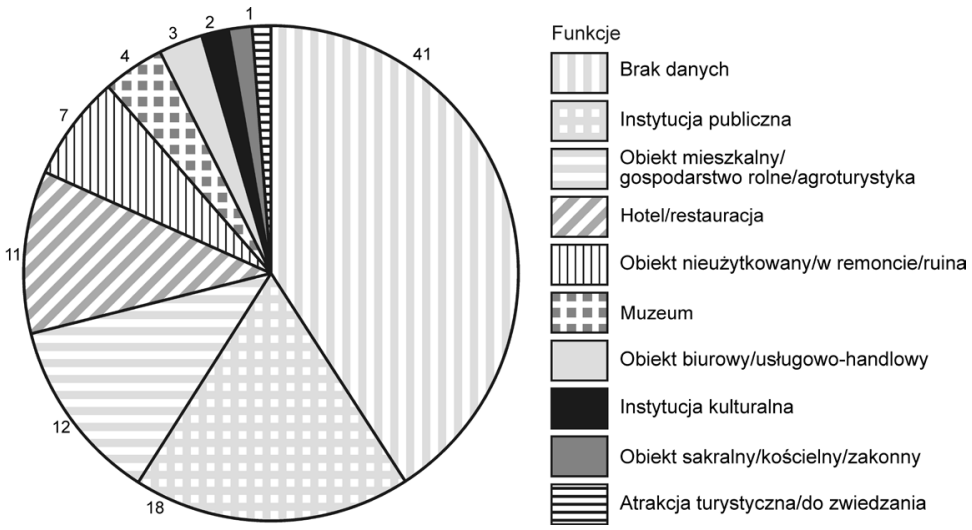

Ryc. 13. Pałace w Polsce według obecnie pełnionej funkcji

Źródło: oprac. własne

W przypadku zamków, konieczne było utworzenie nieco innej klasyfikacji funkcji. Badania wykazały, że zamki (szczególnie te największe założenia), często łączyły w sobie wiele funkcji, co powodowało trudności w jednoznacznym określeniu właściwej kategorii. Ze względu na inny charakter tych zabytków, niektóre wyznaczone wcześniej kategorie były w tym przypadku puste, co spowodowało konieczność ich modyfikacji. W ten sposób wyróżnione zostały:

- atrakcja turystyczna/do zwiedzania,

- hotel/restauracja,

- hotel/restauracja/muzeum,

- muzeum,

- instytucja kulturalna,

- instytucja publiczna,

- teren prywatny/nieużytkowany.

W przypadku zamków, struktura pełnionych funkcji różni się od struktury dworów i pałaców. Dla 36\% zamków nie udało się określić obecnie pełnionej funkcji. Spośród pozostałych najwięcej pełni funkcję muzealną (19\% i 1\% wraz z hotelem i restauracją). Uwidoczniły się obiekty udostępnione do zwiedzania jako atrakcja turystyczna, nie pełniące innej funkcji, które w poprzednich rodzajach zabytków nie były znaczące 9 . Wyróżnia się również funkcja zdefiniowana

${ }^{9}$ Należy podkreślić, że wszystkie analizowane w opracowaniu obiekty (zamki, pałace i dwory) mogą być przedmiotem zainteresowania turysty, a więc mogą pełnić rolę atrakcji 
jako teren prywatny/nieużytkowany. Istotne są też zamki, w których mieszczą się hotele i restauracje (ryc. 14). Jak zauważa M.R. Koskowski (2017), na szczególną uwagę zasługują komercyjne funkcje dużej liczby zamków (funkcja konferencyjna, galeria, restauracja). Są one, według autora, odpowiedzią na wymagania gospodarki rynkowej, co głównie widoczne jest w wypadku obiektów, które nie są własnością państwową. Pozwala to na stwierdzenie, że urynkowienie dziedzictwa kulturowego jest skutkiem zmian zachodzących w sposobie myślenia o zabytkach i ich wykorzystaniu.

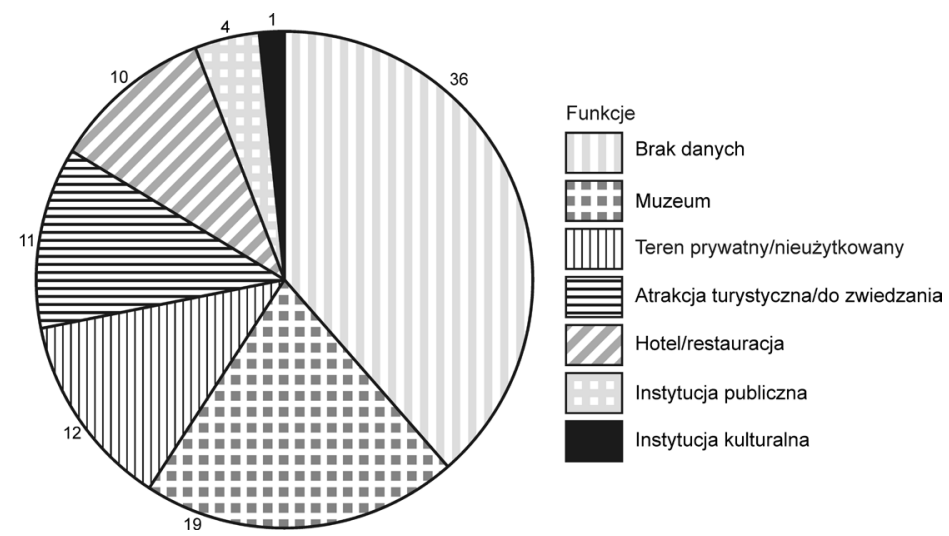

Ryc. 14. Zamki w Polsce według obecnie pełnionej funkcji

Źródło: oprac. własne

\section{Podsumowanie i wnioski}

Dziedzictwo kulturowe i różne jego składniki są bardzo ważnym i ciągle aktualnym tematem badań. W Polsce znaleźć można wiele ciekawych zabytków, które są często niedoceniane i mało znane. Szczególnym zainteresowaniem cieszą się zamki, pałace i dwory, których liczba w Polsce jest ciągle wartością dyskusyjną.

Zgodnie z głównym celem opracowania przedstawiono wyniki projektu studenckiego, w ramach którego zidentyfikowano zamki, pałace i dwory w Polsce oraz pokazano ich charakterystykę pod względem rozmieszczenia, stanu zachowania, stosunków własnościowych oraz aktualnie pełnionej funkcji. Zgodnie z drugim celem pracy, zaprezentowano proces pozyskania danych z użyciem GIS przez studentów oraz oceniono zgromadzone dane i wykorzystaną do tego aplikację. W przedstawionych badaniach brała udział grupa 24 studentów, którzy podczas projektu zidentyfikowali, wprowadzili lokalizacje zabytków w postaci punktów oraz przypisali im odpowiednie atrybuty. Łącznie w ciągu 60-godzinnego

turystycznej. W tej wyróżnionej kategorii uwzględniono tylko obiekty, które zostały udostępnione do zwiedzania, a nie posiadają żadnej innej funkcji. 
przedmiotu wstawiono i opisano 4842 obiekty (307 zamków, 2557 dworów i 1978 pałaców). Pracę udało się sprawnie wykonać dzięki możliwościom aplikacji ArcGIS Online oraz zaangażowaniu studentów i osób prowadzących zajęcia. Interaktywny podkład mapy, dołączone warstwy pomocnicze, możliwość współpracy grupy osób i zapis danych w jednym miejscu znacznie usprawniły cały proces pozyskania danych. Należy mieć jednak na uwadze, że pozyskane dane mogą zawierać błędy i braki w pewnym zakresie, jednak dla tak dużego obszaru badań, krótkiego okresu trwania projektu i braku finansowania, wyniki są zadowalające i pozwalają na wstępną ocenę rozmieszczenia zamków, pałaców i dworów w Polsce oraz ich funkcji, własności i stanu zachowania. Potwierdzają to również wyniki zbliżone do efektów prac innych wymienionych badaczy.

W wyniku prowadzonych badań, w Polsce zidentyfikowano najwięcej założeń dworskich, których największe nagromadzenie zaobserwowano w centralnej części kraju. Zamki występują głównie w południowo-zachodniej oraz północnej części Polski, z kolei najwięcej pałaców odnaleźć można na zachodzie kraju. Najwięcej badanych obiektów występuje w województwach: wielkopolskim i dolnośląskim, a najmniej w województwie podlaskim. Spośród wszystkich przedstawionych zabytków $60 \%$ zostało uznanych za obiekty funkcjonujące. Prawie połowę (49\%) zabytków stanowią obiekty prywatne, a 25\% to własność państwowa lub samorządowa. Najtrudniejszą częścią zadania okazało się określenie obecnie pełnionej przez obiekty funkcji. W tym przypadku, aż dla $40 \%$ analizowanych obiektów, pełniona funkcja nie została przypisana. Wśród pozostałych dominowała funkcja mieszkalna (głównie dla dworów i pałaców). Na uwagę zasługują także instytucje publiczne oraz hotele i restauracje. W przypadku zamków wyróżnia się również funkcja muzealna, a także atrakcja turystyczna oraz ruiny. Oczywiście w celu zmniejszenia brakujących danych, warto byłoby w przyszłości rozszerzyć badania o badania terenowe wraz z dokumentacją fotograficzną oraz dokonać dokładniejszej kwerendy literatury i źródeł internetowych.

$\mathrm{W}$ badaniach dziedzictwa kulturowego nieocenione stają się systemy informacji geograficznej, które dzięki specjalistycznemu oprogramowaniu i technologii pozwalają na szybsze zbieranie danych przestrzennych oraz ich wizualizację $\mathrm{i}$ analizę. Pozyskane dane, chociaż (jak wykazały przeprowadzone analizy) wymagają dalszego porządkowania, zapisane w postaci przestrzennej bazy danych stanowią cenne źródło informacji. Powstała baza danych może być wykorzystana do wielu celów, zarówno naukowych, edukacyjnych, jak i praktycznych, w monitorowaniu stanu zabytków, ich ochrony, a także promocji dziedzictwa kulturowego. Może stanowić punkt wyjścia do dalszych badań, analiz i wizualizacji zarówno w skali kraju, jak i w skali poszczególnych regionów. Kluczowe jest jednak dalsze jej sprawdzanie, aktualizowanie, rozwijanie i uzupełnianie brakujących informacji. 


\section{Literatura}

Chias P., Abad T., Echeverria E., Da Casa F., Celis F., 2006, A GIS in cultural heritage based upon multiformat databases and hypermedial personalized queries, XXI International CIPA Symposium: 1-5.

Droj G., 2010, Cultural Heritage Conservation by GIS, Társadalom - térinformatika kataszter, GISopen konferencia: 1-6.

Guerquin B., 1984, Zamki w Polsce, Arkady, Warszawa.

He J., Liu J., Xu S., Wu C., Zhang J., 2015, A GIS-based cultural heritage study framework on continuous scales: A case study on $19^{\text {th }}$ century military industrial heritage, The International Archives of the Photogrammetry, Remote Sensing and Spatial Information Sciences, XL-5/W7: 215-222.

Hełpa-Liszkowska K., 2013, Dziedzictwo kulturowe jako czynnik rozwoju lokalnego, „Studia Oeconomica Posnaniensia”, 1: 5-18.

Hosse K., Schilcher M., 2003, Temporal GIS for analysis and visualisation of cultural heritage, Institute of Geodesy, GIS and Land Management, Technical University of Munich: 1-6.

Jackiewicz-Garniec M., Garniec M., 2001, Pałace i dwory dawnych Prus Wschodnich, Studio Arta, Olsztyn.

Jasiński J., 2015, Analiza stanu zabytków nieruchomych oraz ograniczeń w zakresie ich obrotu rynkowego w Polsce, „Acta Scientiarum Polonorum Administratio Locorum”, 14: 21-39.

Jażdżewska I., 2010, Zastosowanie Systemów Informacji Geograficznej (GIS) w zachowaniu dziedzictwa kulturowego, Krajowa Konferencja „Rola nauki w zachowaniu dziedzictwa kulturowego", Łódź, 27.11.2010: 167-183.

Koskowski M.R., 2017, Dziedzictwo kulturowe w przestrzeni turystycznej na przykładzie zamków w Polsce, [w:] Orłowski D. (red.), Przestrzeń turystyki kulturowej, Wyższa Szkoła Turystyki i Języków Obcych w Warszawie, Warszawa: 69-83.

Kozak M., 2008, Dwory, pałace i zamki - kosztowne pamiątki czy zasób w rozwoju?, „Studia Regionalne i Lokalne”, 2: 92-111.

Kozakiewicz S. (red.), 1976, Słownik terminologiczny sztuk pięknych, Państwowe Wydawnictwo Naukowe, Warszawa.

Krakowiak B., Latosińska J., 2009, Muzea $w$ dawnych rezydencjach-zamkach, pałacach $i$ dworach, ,Turyzm/Tourism”, 1: 43-50.

Malawska I., 2007, Zamki w Polsce - problem określenia zasobu, „Ochrona Zabytków”, 4: 81-92.

Meyer E., Grussenmeyer P., Perrin J.P., Durand A., Drap P., 2007, A web information system for the management and the dissemination of Cultural Heritage data, ,Journal of Cultural Heritage", 8: 396-411.

Miłobędzki A., 1982, Polskie rezydencje wieku XVII - typowe programy i rozwiazania, [w:] Architektura rezydencjonalna historycznej Małopolski, Materiały Sesji Stowarzyszenia Historyków Sztuki, Łańcut, czerwiec 1975: 7-17. 
Musiaka Ł., 2013, Funkcja turystyczna zamków państwa zakonu krzyżackiego w granicach Polski, „Turyzm”, 23: 55-64.

Musiaka Ł., 2016, Funkcja turystyczna zamków dawnego państwa krzyżackiego na przykładzie Malborka, [w:] Hochleitner J. (red.), Wyzwania Turystyki Kulturowej w Malborku, Muzeum Zamkowe w Malborku, Malbork: 23-42.

Rinaudo F., Agosto E., Ardissone P., 2007, GIS and WEB-GIS, commercial and open source platforms: General rules for cultural heritage documentation, International archives of the photogrammetry, remote sensing and spatial information sciences, XXXVI-5/ C53: 625-630.

Rouba R., 2010, Hotelarstwo w zabytkowych rezydencjach jako czynnik modyfikujacy otoczenie, Łódzkie Towarzystwo Naukowe, Łódź.

Rouba R., Cudny W., 2010, Monitorowanie zabytkowych rezydencji funkcjonujacych na rynku ustug hotelarskich w Polsce w latach 2002-2011, „Ochrona Zabytków”, 1-4: 183-198.

Rydel M., 1993, Jam dwór polski, Fundacja Rozwoju Uniwersytetu Gdańskiego, Gdańsk.

Rydel M., 2012, Dwór - polska tożsamość, Wydawnictwo Zysk i S-ka, Poznań.

Rząsa K., Ciski M., Ogryzek M., 2019, Application of GIS Tools in Spatial Distribution Modeling of Historical Monuments, „Geomatics and Environmental Engineering, 13: 61-71.

Seker D.Z., Alkan M., Kutoglu H., Akcin H., Kahya Y., 2010, Development of a GIS based Information and Management System for Cultural Heritage Site; Case Study of Safranbolu, FIG Congress - Facing the Challenges - Building the Capacity: 1-10.

Siniecka A., Bogacka E., 2018, Dziedzictwo kulturowe województwa wielkopolskiego w świetle danych Narodowego Instytutu Dziedzictwa. Przykład zabytków nieruchomych, „Rozwój Regionalny i Polityka Regionalna”, 44: 53-66.

Spiridon P., Ursu A., Sandu I., 2016, Heritage management using GIS, Cartography and GIS: $263-270$.

Szady B., 2016, Spatio-temporal databases as research tool in historical geography, „Geographia Polonica”, 89: 359-370.

Szajnowska-Wysocka A., Tkocz M., 2008, Funkcje rekreacyjne obiektów rezydencjonalnych $w$ regionie ślaskim, „Acta Geographica Silesiana”, 4: 37-45.

Toz G., Duran Z., 2004, Documentation and analysis of cultural heritage by photogrametric methods and GIS: A case study, ITU, Civil Engineering Faculty: 1-4.

Worboys M., Duckham M., 2004, GIS: A computing perspective, CRC Press.

Yakar M., Doğan Y., 2018, GIS and three-dimensional modeling for cultural heritages, „International Journal of Engineering and Geosciences (IJEG)”, 3: 50-55.

Ziółkowska-Weiss K., Popiel M., 2014, Rozwój turystyki dziedzictwa na wybranych przykładach w Polsce, ,Annales Universitatis Paedagogicae Cracoviensis Studia Geographica", 7: 133-147.

Ustawa z dnia 23 lipca 2003 roku o ochronie zabytków i opiece nad zabytkami (Dz.U., 2003, nr 162, poz. 1568). 


\title{
Netografia
}

https://jbc.bj.uj.edu.pl (dostęp: 9.02.2021).

https://nid.pl (dostęp: 20.08.2020).

https://www.esri.com (dostęp: 17.08.2020).

\section{Castles, palaces and manors in Poland - location and current use}

\begin{abstract}
The aim of this chapter was to identify castles, palaces and manors in Poland and to characterize them in terms of their distribution, state of preservation, ownership relations and current function. The intermediate aim was to present the process of data collection using GIS, evaluation of the collected data and the software used. The research was carried out as part of a student project. On the basis of the register of immovable monuments of the National Heritage Institute, locations and descriptive information for 4842 castles, palaces and manors in Poland were collected using ArcGIS Online application. Of all classified objects, nearly 53\% are manors, $41 \%$ palaces, and $6 \%$ castles. Most manors are located in the center of Poland. Palaces dominate in the western part of the country. Castles are located mainly in the south-western part of Poland and to a lesser extent in the north. Among the analyzed monuments, $60 \%$ are considered as functioning objects. Nearly half of all castles, palaces and manors included in the project are private objects. The most common current function of the analyzed monuments is residential function $(18 \%)$.
\end{abstract}

Keywords: cultural heritage, castles, palaces, manors, GIS, ArcGIS Online.

Mgr Angelika Jasion

Uniwersytet Łódzki

Wydział Nauk Geograficznych

Instytut Geografii Miast, Turyzmu i Geoinformacji

e-mail: angelika.jasion@edu.uni.lodz.pl

(iD) https://orcid.org/0000-0003-1632-2613

Dr Jolanta Latosińska

Uniwersytet Łódzki

Wydział Nauk Geograficznych

Instytut Geografii Miast, Turyzmu i Geoinformacji

e-mail: jolanta.latosinska@geo.uni.lodz.pl

(D) https://orcid.org/0000-0003-4886-7853 